\title{
Impact Assessment of Mining and Geological Factors of Kuzbass Coal Mines on the Level of Their Power Consumption
}

\author{
Zakharova Alla $G^{a}$., Lobur Irina $A^{\mathrm{b}}$., Shauleva Nadezda $\mathrm{M}^{\mathrm{c}}$., Borovtsov Valeriy A. ${ }^{\mathrm{d}}$ \\ T. F. Gorbachev Kuzbass State Technical University \\ Kemerovo, Russian Federation \\ azaharova8@gmail.com; ${ }^{b}$ lovuriska@mail.ru; ${ }^{\mathrm{c}}$ anaa5283@mail.ru; \\ ddekanat.gemf@yandex.ru
}

\begin{abstract}
The processing results of the extensive statistical material characterizing the level of power consumption of Kuzbass coal mines are presented. At the same time, in the formulation of the research problems, the authors have come from the fact that the power consumption of mine is a function of many variables. This has revealed the tendencies not only in development of power consumption, but also many other factors determining its level: deepening of mining operations, growth of gas content and, therefore, increase in electric power costs for ventilation of mine roads, increase in water inflow, etc. On the basis of statistical researches it is shown that the worsening of mining-and-geological conditions of Kuzbass coal mines leads to an increase in specific consumption of the electric power. Quantitative estimates of the impact of the mining-and-geological and mining factors on the mine power consumption are established. The presented results can be used to solve the task of increasing the efficiency of power usage in the coal mines, both at the design stage, and during normal operations of the enterprise.
\end{abstract}

Keywords - coal-mining enterprise; coal mines; energy efficiency; forecasts; mathematical model; regularities of a power consumption

\section{INTRODUCTION}

The energy saving problem at the coal-mining enterprises consists not only in the decrease in costs of energy resources of coal production, but also in rational arrangement of the entire system of power supply assuming a level of losses and expenses in all links at a high level of reliability. The solution of this problem is possible on the basis of establishment of quantitative regularities of energy costs formation and receiving reliable predictive estimates on their basis [1][2].

The level of power consumption in underground mining operations to a significant extent is determined by the geological conditions of mines or certain deposits of the coal basin, and therefore, for the development of measures aimed at energy conservation, it is necessary to have the results of the analysis of generalized characteristics of the basin mines and the factors that determine the level of power consumption [3][4] [5].

\section{MATERIALS AND METHODS}

The analysis of the change in mining-and-geological conditions of Kuzbass mines was carried out on the basis of available results of observations for quite a long period (about 25 years). Data collection was carried out on 25 mines with different mining and geological and mining-technical conditions included in the coal companies of the Kemerovo, Leninsk-Kuznetsk, Belovo and Prokopevsk-Kiselevsk districts of Kuzbass. The data revealed stable operating patterns and allowed their use in the appropriate models. At the same time it was accepted as a working hypothesis that mine power consumption level is defined by its production capacity, depth of conducting mining operations, gas content (and, therefore, amount of the air given to mine), a water profuseness and extent of excavations. The intensification of technological processes, concentration of mining operations and complication of mining-and-geological conditions, in particular, of development depth and gas content promotes the further growth of electric installations capacities and increase of electric loadings and causes new difficulties in creation of safe and economic systems of mine power supply [6] [7] [8].

As a result of data processing by the known techniques mathematical models (the regression equation) suitable for forecasting with a certain accuracy of nature of the studied factors change have been received [11] [13] [22].

\section{RESULTS AND DISCUSSIONS}

It is known that the measure of electric power expenditure serves the specific expense of the electric power (SEEP) which in Kuzbass mines varies over a wide range: from 18 to $245 \neg \mathrm{kW}$ of $\mathrm{h} / \mathrm{t}[7,14]$.

The analysis has shown that for the last 25 years SEEP has increased on average by $1.5-2.3$ times though in some years (for example, after the restructuring of the coal industry which is carried out in the 90th years) the absolute power consumption decreased because of reduction of extracted coal volumes. On average decrease in coal mining by $1 \%$ led to increase in a specific power consumption by $1.15 \%$. This tendency remained until the end of 1998. And only by the end of 1999 when in the field of economy the steady tendency to increase in growth of coal mining was outlined, the ratio in dynamics of these two indicators has changed [15] [16] [23]. 
The analysis of the modes of the power consumption during the years of observations has shown existence and action of two main regularities. The first of them is increase in a constant component in SEEP caused by growth of a relative share of its expense on ventilation of mine workings and on water outflow, and also decrease in an expense on production and transportation of coal. It demonstrates that in the course of a power consumption of mines the leading role is carried out by the consumers providing creation of safety conditions, but not technological consumers [14] [17] [18].

The other tendency shows that regardless of the alleconomic factors influencing the general condition of coal branch and the national economy of the country in general there is a steady increase in SEEP by $4.4-9.1 \%$ per year in relation to the last year.

It is convenient to investigate the reasons of the developing tendencies in development of process of a power consumption by means of the statistical methods allowing to receive the generalized picture for mines of the basin in general. The generalizing feature for the Kuzbass mines is the dip angle of mined seams which at a relatively small change in their thickness within the same field to a large extent determines the technology and techniques used to mine the minerals.

The available statistical data have allowed to obtain regression equations connecting power consumption level with duration of operation of mines provided that in the next years there will be certain technological changes at the mines and the structure of a power consumption will remain the same [15] [18] [20].

For mines of Leninsk-Kuznetsky and Prokopyevsk Kiselevsky areas of fields and the Kuznetskugol coal company (CC) these equations are given in Table 1 , where $\mathrm{w}-$ specific energy consumption, $\mathrm{kWh} / \mathrm{t}$; $\mathrm{K}$ - number of year for SEEP, since 1997 (for 1997 . $\mathrm{K}=0$, etc.).

TABLE 1 - DEPENDENCES OF A POWER CONSUMPTION LEVEL ON DURATION OF MINES OPERATION.

\begin{tabular}{|l|c|c|c|c|}
\hline $\begin{array}{c}\text { Area of the } \\
\text { field, company }\end{array}$ & $\begin{array}{c}\text { Regression } \\
\text { equation, } \mathbf{k W} \\
\text { of } \mathbf{h} / \mathbf{t}\end{array}$ & $\begin{array}{c}\text { Coefficient } \\
\text { of } \\
\text { correlation }\end{array}$ & $\begin{array}{c}\text { Mean } \\
\text { square } \\
\text { deviation, } \\
\mathbf{k W} \text { of } \mathbf{~} / \mathbf{t}\end{array}$ & $\begin{array}{c}\text { \% } \\
\text { gain }\end{array}$ \\
\hline $\begin{array}{l}\text { Leninsk- } \\
\text { Kuznetsky }\end{array}$ & $\mathrm{w}=3.04 \mathrm{~K}+40$ & 0.74 & 7.16 & 7.6 \\
\hline $\begin{array}{l}\text { Prokopyevsk - } \\
\text { Kiselevsk }\end{array}$ & $\mathrm{w}=1.66 \mathrm{~K}+50$ & 0.63 & 4.13 & 3.3 \\
\hline $\begin{array}{l}\mathrm{CC} \text { "Kuznetsk- } \\
\text { ugol" }\end{array}$ & $\mathrm{w}=1.8 \mathrm{~K}+42.5$ & 0.52 & 4.44 & 4.2 \\
\hline
\end{tabular}

The field of correlation between SEEP and production level for the Kuzbass mines working in approximately similar conditions is presented in Fig. 1. The following equation of regression is fair for the above field:

$$
\mathrm{w}=45.3 \mathrm{D}^{-0.48}, R^{2}=0.71,
$$

where $\mathrm{D}$ - annual production, one million $\mathrm{t} ; R^{2}$ - determination coefficient which can be treated as a part of dispersion "explained" with the equation of regression [11].
It follows from the equation (1) that increase in production in mines where it doesn't reach 1 million tons/year and where there are reserve production capacities of underground transport, hoistin and surface handling facilities capable to take up increasing coal stream, is one of energy saving ways [22] [25].

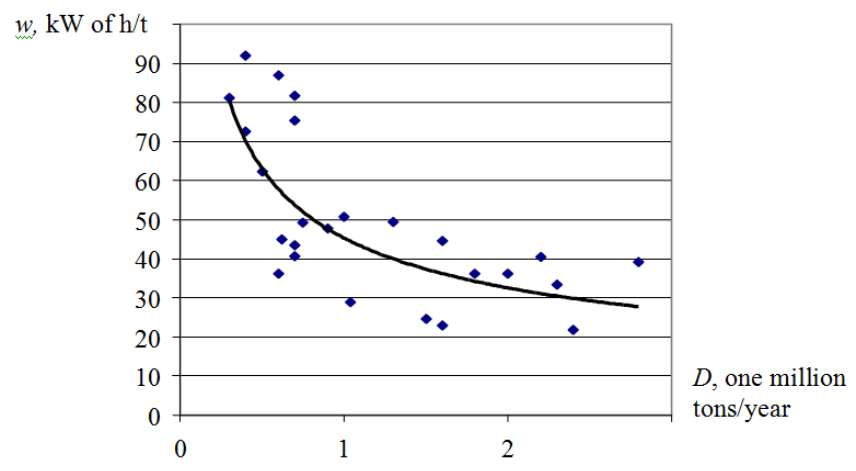

Fig. 1. - The field of correlation and a curve of regression between SEEP and production

Meanwhile, during the work of mines also other processes take place owing to which SEEP is increased with the increase of life of mine period [15] [18] [20]. The regression equations between SEEP and duration of operation are given in Table 2. Here $K$ - number of year since 1988 (for 1988. $K=0$, etc.). High values of correlation factor indicate rather rigid interrelation between increase of SEEP and duration of mines operation period.

TABLE 2 - DEPENDENCES OF SEEP ON DURATION OF MINES OPERATION PERIOD.

\begin{tabular}{|c|c|c|c|c|}
\hline $\begin{array}{c}\text { Area of the } \\
\text { field, company }\end{array}$ & $\begin{array}{c}\text { Regression } \\
\text { equation, } k W \\
\text { of } h / t\end{array}$ & $\begin{array}{c}\text { Coefficient } \\
\text { of } \\
\text { correlation }\end{array}$ & $\begin{array}{c}\text { Mean } \\
\text { square } \\
\text { deviation, } \\
\mathrm{kW} \text { of } \mathrm{h} / \mathrm{t}\end{array}$ & $\begin{array}{c}\% \\
\text { gain }\end{array}$ \\
\hline Kemerovo area & $\mathrm{w}=1.14 \mathrm{~K}+34.5$ & 0.66 & 7.98 & 3.3 \\
\hline $\begin{array}{l}\text { Leninsk- } \\
\text { Kuznetsky } \\
\text { branch "SUEK" }\end{array}$ & $\mathrm{w}=1.34 \mathrm{~K}+23.4$ & 0.637 & 6.18 & 5.7 \\
\hline "Belovougol" & $\mathrm{w}=0.71 \mathrm{~K}+1.8$ & 0.573 & 3.89 & 4.2 \\
\hline $\begin{array}{l}\text { Prokopyevsk - } \\
\text { Kiselevsk area }\end{array}$ & $\mathrm{w}=1.44 \mathrm{~K}+21.3$ & 0.58 & 7.49 & 6.7 \\
\hline $\begin{array}{l}\text { "Kuznetskugol" } \\
\text { North-South }\end{array}$ & $\begin{array}{c}\mathrm{w}=1.12 \mathrm{~K}+17.05 \\
\mathrm{w}=1.11 \mathrm{~K}+21.7\end{array}$ & $\begin{array}{l}0.67 \\
0.55\end{array}$ & $\begin{array}{c}4.67 \\
6.2\end{array}$ & $\begin{array}{c}6.55 \\
5.1\end{array}$ \\
\hline
\end{tabular}

Calculations for the received equations show that by 2017 SEEP can be increased on average by $1.3-1.4$ times in comparison with 2009. It means that the SEEP minimum value can be increased to $31-33 \mathrm{kWh} / \mathrm{t}$, maximum - to 220 $250 \mathrm{kWh} / \mathrm{t}$, and the average value for mines of the basin can make $67-72 \mathrm{kWh} / \mathrm{t}$ at average SEEP in $200952.6 \mathrm{kWh} / \mathrm{t}$. If to keep the annual volume of underground production in the basin at the level of $90-95$ million t., that absolute electricity consumption can increase up to $4.7-4.9$ billion $\mathrm{kW}$ of $\mathrm{h} / \mathrm{t}$ instead of 3.5 billion $\mathrm{kW}$ of $\mathrm{h} / \mathrm{t}$ in 2009. The received dependences in the statistical way and the executed calculations on their basis reflect the general tendency of change for Kuzbass mines of their main mining-andgeological and technical characteristics [16] [24]. 
The general tendencies of increase in power consumption on coal mines are displayed also on growth of this indicator depending on a water profuseness. The regression equations between SEEP on water outflow $w_{6}$ and a water profuseness are given in Table 3. Inflow of water $\mathrm{V}, \mathrm{m}^{3}$ on $1 \mathrm{t}$ of production is accepted as this indicator. Apparently from Table 3 , in mines with steeply dipping seams, coefficients of correlation are rather small, however such link nevertheless is traced.

Using the regression equations given in Table 3 , the required amount of electricity for pumping can be calculated which is an increase of water profuseness in connection with the deepening of mining operations on average by $1.2-2.8 \%$ in the year.

The average growth water profuseness closely correlated with increasing depth development of mines for the last seven years in the range of $3.4-4.6 \%$ in the year. Spring water inflow increases relatively normal 1.2 is 1.8 times and depends on the specific hydrogeological conditions of the developed area of the deposit.

The relative gas content of mines varies from 0,8 to 146,6 $\mathrm{m} 3 / \mathrm{t}$. As it was mentioned above, the gas content of mines determines in an essential rate an electric power expense on ventilation.

TABLE 3 - DEPENDENCES OF SEEP ON WATER OUTFLOW FROM A WATER PROFUSENESS

\begin{tabular}{|l|c|c|c|}
\hline $\begin{array}{c}\text { Area of the field, } \\
\text { company }\end{array}$ & $\begin{array}{c}\text { Regression } \\
\text { equation, } \mathbf{k W} \text { of } \mathbf{h} / \mathbf{t}\end{array}$ & $\begin{array}{c}\text { Coefficie } \\
\text { nt of } \\
\text { correlatio } \\
\mathbf{n}\end{array}$ & $\begin{array}{c}\text { Mean } \\
\text { square } \\
\text { deviation, } \\
\mathbf{k W} \text { of } \mathbf{~} / \mathbf{t}\end{array}$ \\
\hline Kemerovo area & $\mathrm{wB}=0.25 \mathrm{~V}+5.04$ & 0.347 & 0.97 \\
\hline $\begin{array}{l}\text { Leninsk- } \\
\text { Kuznetsky branch } \\
\text { "SUEK" }\end{array}$ & $\mathrm{wB}=1.16 \mathrm{~V}+7.36$ & 0.83 & 0.91 \\
\hline "Belovougol" & $\mathrm{wB}=0.22 \mathrm{~V}+5.22$ & 0.33 & 0.66 \\
\hline Prokopyevsk - & $\mathrm{wB}=0.76 \mathrm{~V}+3.65$ & 0.78 & 0.65 \\
Kiselevsk area & $\mathrm{wB}=0.91 \mathrm{~V}+6.95$ & 0.59 & 0.607 \\
\hline |"Kuznetskugol" & $\mathrm{wB}=1.01 \mathrm{~V}+5.31$ & 0.68 & 0.8 \\
\hline North - South & \multicolumn{2}{|l}{} \\
\hline
\end{tabular}

The calculation results of relative SEEP changing on ventilation (the curve 1 corresponds to coal mining by mine of 600 thousand tons/year, and curve $2-1000$ thousand tons per year) depending on gas content of mine are given in Fg. 2 [16] [23]. It is visible that with growth of gas content from 1 to 25 $\mathrm{m} 3 / \mathrm{t}$ the specific weight of the electric power expense on ventilation constantly increases, reaching level about $55-72 \%$ at the gas content equal to $25 \mathrm{~m} 3 / \mathrm{t}$. Curves 3 and 4 in this drawing show how the share of relative electricity consumption on underground production and transport for mines of the same productivity changes.

As noted above similar dependences are received in the analysis of a power consumption on water outflow at growth of depth of performing works by $2,4-4,5 \%$ a year. Despite the increase in depth of excavation, relative expenses of the electric power of these purposes don't increase as expenses of ventilation grow with an essential advancing.
Thus, electric power expenses on ventilation of underground headings and faces at a certain rate form a power consumption of mine. Comparison of structure of the power consumption in the mines operating now testifies in favor of such conclusion as well shown in Table 4.



Fig. 2. - Dependence of relative SEEP on gas content of mine: 1, 2 - on airing; 3, 4 - on production and underground transport for mines of various productivity

Heavy expenses of the electric power on airing are explained by several reasons, including irrational application of the air given to mine and big extent of excavations. According to the data, [22] [24] [25] depression (compression) of fans in mines varies within 17 - 380 (differs by 22,3 times), and the aerodynamic resistance of systems of ventilation 0,17 - 104 (by 611 times), the consumption of air makes $41-$ $847 \mathrm{~m} 3 / \mathrm{s}$ (by 20,6 times), and internal leaks - from 7,3 to $34,2 \%$; the useful coefficient of air makes $0,5-0,86$. It is obvious that rationalization of airing systems, decrease in aerodynamic resistance of excavations and a depression (compression) of fans is a very essential reserve of decrease in power consumption of coal mines.

TABLE 4 - COMPARISON OF STRUCTURE OF A POWER CONSUMPTION IN MINES

\begin{tabular}{|l|l|l|}
\hline \multicolumn{1}{|c|}{ Groups of electroreceivers } & \multicolumn{2}{|c|}{$\begin{array}{c}\text { Average electricity } \\
\text { consumption, \% }\end{array}$} \\
\cline { 2 - 3 } & $\mathbf{1 9 9 5}$ & $\mathbf{2 0 0 9}$ \\
\hline $\begin{array}{l}\text { Technological operations of production and } \\
\text { transportation of coal (without rise) }\end{array}$ & 18.7 & $9.3-15.7$ \\
\hline Water-removing installations (high-voltage) & 28.0 & $13.9-30.7$ \\
\hline $\begin{array}{l}\text { Airing of underground developments and faces } \\
\text { (without fans of local airing) }\end{array}$ & 33.1 & $25.4-60.2$ \\
\hline Lifting equipment & 13.2 & $9.6-16.8$ \\
\hline $\begin{array}{l}\text { Auxiliary equipment and lighting (including } \\
\text { on a surface) }\end{array}$ & 6.3 & $4.1-8.5$ \\
\hline Preparatory work & 0.7 & 2.9 \\
\hline
\end{tabular}

The reduction of the number of the working fans of the main ventilation is one more reserve. Researches have shown that in overall balance of energy consumption in ventilator equipment $7.8-10.3 \%$ make losses in the drive, $26.8-44.9 \%$ - in the fan, $18.6-29.4 \%$ - in surface ventilating constructions, and only $18.8-44.3 \%$ are the useful energy realized on ventilation of mine workings. Calculations show that only due to reduction of the number of the working fans by $50 \%$ on the basis of rationalization of ventilation systems it 
is possible to reduce energy consumption for these purposes by $28-32 \%$.

\section{CONCLUSION}

Thus, on the basis of statistical researches it is defined that the worsening mining-and-geological and technological conditions of coal mines (deepening of mining operations and increase in relative gas content) lead to increase and a specific expense of the electric power. The greatest expenses of the electric power fall on ventilation of mine workings and faces that in the next years can lead to growth of energy consumption in coal mines by $1.5-1.6$ times. Decrease in energy consumption is possible due to rationalization of ventilation systems and reduction of working fans number because power losses in them and in ventilating constructions reach $55-70 \%$.

\section{ACKNOWLEDGMENT}

We express gratitude to Razgildeev Gennady Innokentyevich, the Doctor of Engineering, professor, the academician of the Russian Academy of Natural Sciences, the academician of RIA; to the honored science and engineering figure of the Russian Federation, the expert in the field of reliability, safety and profitability of electric equipment and systems of power supply of the mining enterprises for the help in work process in research of problems of power consumption modeling in Kuzbass coal mines.

\section{REFERENCES}

[1] Pivnyak, G.G., V.T. Zaika and V.V. Samoilenko, 2006. Methods and tools for power manage-ment process of underground coal mining. Electrician, 6: 3-7.

[2] Shushukin, A.I., 2008. Power plants: reliability, efficiency, energy saving. SPb: GCE-Energy, pp: 302.

[3] Pivnyak, G.G., 2004. A mining enterprise as an object of consumption. Mining journal, 7: 3-5.

[4] The Outlook for energy in the world and Russia to the year 2040, 2014. Moscow: ERI RAS, pp: 175.

[5] Plakitkina, L.S., 2013. Analysis and prospects of development of the coal industry, major coun-tries, the former USSR and Russia in the period up to 2030. Moscow: Mining industry, pp: 416.

[6] Zakharova, A.G., 2002. The patterns of electricity consumption at coal mines of Kuzbass: Monograph. Kemerovo: Kuzbass State Technical University, pp: 198.

[7] Belih, B.P., I.S. Sverdel and V.K. Oleinikov, 1971. Electric load and consumption by mining enterprises. Moscow: Nedra Publishers, pp: 247.

[8] Oleinikov, V.K. 1983. Analysis and planning of energy consumption on the mountain predprijatiakh. Moscow: Nedra Publishers, pp: 192.

[9] Levin, Devid M., Stefan, Devid, Krebil', Timoti S., 2014. Berenson, Mark L. Statistika dlya menedzherov s ispol'zovaniem Microsoft Excel, 4-e izd. - Moscow: Izdatel'skiy dom «Vil'yams», pp: 1312.
[10] Dreiper, N. and G. Smit, 1973. Applied regression analysis. Moscow: Statistics, pp: 279.

[11] Dougerty, K., 2001. Introduction to econometrics. INFRA, pp: 402.

[12] Stadnik, D.A., 2004. Forecasting and management of electricity consumption of coal mines. Collection of proceedings, Moscow state mining Institute (issue 4), pp: 221-225.

[13] Buryy S. V. , 2013. Razrabotka metoda perspektivnogo planirovaniya elektropotrebleniya s pri-meneniem regressionnykh modeley. Krivoy Rog. Tekhnicheskie sredstva i in-formatsionnye sistemy, ispol'zuemye dlya realizatsii funktsiy upravleniya. Vestnik, 3. pp: 64-68.

[14] Val', P. V and Yu. P. Popov. 2011. Kontseptsiya razrabotki sistemy prognozirovaniya elektropotrebleniya promyshlennogo predpriyatiya $\mathrm{v}$ usloviyakh optovogo rynka. Promyshlennaya energetika. 10: pp:31 - 35 .

[15] Zakharova, A.G. and I.A. Grebenshikova, 2005. The impact of changes in geological con-ditions of the coal mines of Kuzbass on their consumption. Iindustrial energy, 4: 35-37.

[16] Zakharova, A.G. and G.I. Razgildeev, 2000. Structure of consumption of energy and resources saving in the mines of Kuzbass. journal of Coal, 7: 48-50.

[17] Razumnyi, Yu.T., Rukhlova, N.Yu.and Rukhlov, A.V. 2013. "Improvement of energy efficiency of the main dewatering plant of a coal mine", Naukovyi Visnyk Natsionalnoho Hirnychoho Universytetu, no. 5, pp. 67-72.

[18] Pivniak, G.G., Shkrabets, F.P., Zaika, V.T. and Razumnyi Yu.T. 2004. Systemy efektyvnogo energozabezpechennia vygilnykh shakht [Systems of Efficient Energy Supply of Coal Mines], National Mining University, Dnepropetrovsk, Ukraine. - 2004. - 206 c.

[19] Bragin, V.E., P.V. Egorov and E.A. Bober, 1994. Mines Of Kuzbass: Reference. Moscow: Nedra Publishers, pp: 351.

[20] Pivniak, G.G., Zhezhelenko, I.A. and Papaika Yu. 2013. Normalization of voltage quality as the way to ensure energy saving in power supply systems. Energy efficiency improvement of geotechnical systems. International Forum on Energy Efficiency. pp:11-18.

[21] Papaika, Yu.A., Khovanskaya, Ye.I. and Lysenko, A.G. 2012. Safety of electric chains during the use of contactless electric locomotives. Naukovyi Visnyk Natsionalnoho Hirnychoho Universytetu.

[22] Khovanskaya, Ye I, Lysenko, A.G. 2013. Rational modes of traction network operation of transport with inductive power transfer in the coal industry. Energy Efficiency Improvement of Geotechnical Systems Proceedings of the International Forum on Energy Efficiency.

[23] Shkrabets, F. P., Varenik, Ye.A., Savitsky, V.N., and Dziuban, V.S 2013. New generation of explosion-proof electrical equipment complex for mining industry power supply systems. Naukovyi Visnyk Natsionalnoho Hirnychoho Universytetu.

[24] Ivashchenko, V. A., Kolokolov, M. V. and D. A. Vasil'ev. 2013. Prognozirovanie elektropotrebleniya promyshlennykh predpriyatiy na osnove statisticheskikh metodov $\mathrm{i}$ iskusstvennykh neyronnykh setey Izvestiya vuzov. Gornyy zhurnal. 8: pp: 104 - 110.

[25] Sinchuk, O. N. [i dr.] 2010. Metody rascheta elektricheskikh nagruzok sistem elektrosnabzheniya gornykh predpriyatiy. Vestnik Saratovskogo gosudarstvennogo tekhnicheskogo universiteta. 2 (45): pp: 110 - 115. 